\title{
МЕЖАУНАРОАНОЕ ПРАВО
}

УДК $341.1 / 8$

DOI: $10.18287 / 2542-047 \mathrm{X}-2018-4-1-38-46$

Duško Dimitrijević*

\section{TERRITORIAL DISPUTES IN THE EAST CHINA SEA}

The issue of territorial delineation in the East China Sea has a geo-economics significance due to the presence of rich energy sources as well as to the intertwined interests of the coastal states and the interests of the United States, that, for strategic reasons, tends to maintain its political and military presence and control. In the last decade, China, Taiwan and Japan have intensified their territorial demands in the East China Sea over the islands that the Chinese call Diaoyu, Taiwanese Diaoyutai, and the Japanese Senkaku (hereinafter: Senkaku/Diaoyu Islands). Due to the increasingly visible escalation in mutual relations arising from different points of view regarding the sovereignty of these islands and different approaches in terms of determining the boundaries of exclusive economic zones and continental shelves, where no party wants to make concessions to the other party, the application of international law seems an inevitable mechanism for overcoming territorial disputes. In this regard, the study deals with the possibilities to resolve territorial disputes in the East China Sea in order to achieve sustainable legal solutions that would be in accordance with the international law of the sea, and whose application would ensure peace and stability in this part of the world.

Key words: territorial disputes, maritime delimitation, East China Sea, Senkaku/ Diaoyu Islands, China, Taiwan, Japan.

\section{HISTORICAL FACTS AS A BASIS OF SOVEREIGNTY OVER SENKAKU/DIAOYU ISLANDS}

The dispute over the Senkaku/Diaoyu Islands originates from the distant Chinese-Japanese past. Until the 1970s, China, Taiwan and Japan had demanded sovereignty over the islands located half way from Taiwan and the southwestern end of Okinawa. According to Chinese historical artifacts, China was the first to discover and use the islands of Senkaku/Diaoyu. During the time of the Chinese dynasty Ming (from 1368-1644), this area was considered an integral part of the Chinese territory. The island of Senkaku/Diaoyu was officially mentioned in the 15th century, in a document found in the Bodleian Library in Oxford and in the book Shun Feng Xiang Song, published in 1403. Comprehensive evidence of the Chinese affiliation of the island of Senkaku/Diaoyu is found in numerous reports compiled by Chinese emigrants at that time, but also in naval and military charts and defensive documents in which the islands are drawn on a road leading from China to Okinawa. During the Qing dynasty (from 1644-1911), the Senkaku/Diaoyu Islands were under the jurisdiction of Taiwan, which was part of China. As the border between Senkaku/Diaoyu Islands and Okinawa in the 17th century, the area of Heishuigou was taken, which is described in historical sources as the «Black Water Zone» that cultivates the Chinese continental plateau. Historical sources state that in 1720 , the deputy of Chinese Ambassador Xu Baoguang sent a royal sign to the King of Okinawa. Working with local representatives, he succeeded in compiling a travelogue Zhongshan Chuanxin lu, in which the westernmost border of the kingdom of Okinawa in Kume-yima south of Heysheigh was identified on the basis of the record of the mission of Chusan. Something similar was done by the deputy ambassador, Zhou Huang, in 1756, confirming that Heishueigou represents the border between Qui Yi and Kume-jima, while envoy Li Dingyuan noticed that there was a traditional practice of sacrificing domestic animals when crossing the Okinawa basin [1].

In the talks with Japan over the sovereignty of Ryukyu Islands, Li Hongzhang, the Qing dynasty diplomat called to the fact that the Japanese writer Hayashi Shihei noticed in his illustrated geography that the Senkaku/ Diaoyu Islands were not included into the composition of Ryukyu Islands. In the same period, sea charts and geographical maps of large maritime powers such as the United Kingdom, Spain, the United States of America and France portrayed the Senkaku/Diaoyu Islands with a component part of China (e.g. a geographical map called «China's latest map» in Great Britain in 1811, then a ticket was printed in the United States in 1859, etc.). A naval map of the eastern Chinese coast from Hong Kong to the Liaodong Bay built by the British

\footnotetext{
* (C) Dimitrijević Duško, 2018
}

Dimitrijević Duško (dimitrijevicd@diplomacy.bg.ac.rs), Ph.D.,Professorial Fellow and former Director of the Institute of International Politics and Economics, 25, Makedonska Street, 11103, Belgrade, Serbia. 
Navy in 1877 portrayed the Senkaku/Diaoyu Islands as part of Taiwan. In addition, the Senkaku/Diaoyu Islands were clearly separated from the Japanese Nansei (Nansei shotō) or Ryukyu Islands on the maritime chart. After Japan annexed the Ryukyu Islands in 1879 (renaming them to Okinawa Island), Japan began to operate more or less concealed with the aim of occupying the Senkaku/ Diaoyu Island, and finally it was able to do it after the end of the Chinese-Japanese War (1894-1895).

On this occasion, the renowned Chinese state reformer Wang Tao, voiced opposition to Japanese expansionism, pointing out that Japan had no right to join Okinawa since this area was more formally in a vassal relation to the Japanese state of Satsum. However, China was too weak to resist the Japanese military force that quickly occupied the whole of Korea (which was previously China's vassal), as well as strategically important Chinese territories in southern Manchuria, the peninsula Liáodōng, Taiwan and the Pescadores/ Penghy archipelago in the Taiwan Strait. The occupation of the Senkaku/Diaoyu Islands in 1895 was not regarded by China as a legal act under international law.

Japan ignored the Chinese historical and legal arguments, believing that a request for sovereignty over the Senkaku/ Diaoyu Islands stemmed from the fact that the islands were discovered in 1884 by a Japanese sailor Koga Tatsushiro who, after the discovery, asked the Japanese state to be the same lease. However, from the available historical sources relating to this case, it appears that the Japanese authorities at that time were not entirely sure of whether the Senkaku/Diaoyu Islands discovery could be a valid legal basis for the Islands to belong to Japan given that there was no clear evidence to support the merits of this requirement. Therefore, the Japanese government dispatched secret missions to establish relevant facts for the purpose of legitimizing the demand that the Senkaku/Diaoyu Islands should belong to Japan. Given that the contested islands were not inhabited or occupied by any country as «no one's land» (terra nullius), Japan, on the basis of a decision of the Imperial Council of Ministers on January 14, 1895, put the Senkaku/Diaoyu Islands under the administrative power of the Okinawa Prefecture. Shortly after the victory in the Sino-Japanese War, on April 17, 1895, Japan and China signed the Peace Treaty in Shimonoseki, on the basis of which Taiwan (Formosa), along with all accompanying islands, was transferred to Japan. It is interesting that the Peace Treaty of Shimonoseki did not mention that the Senkaku/Diaoyu Islands were simultaneously transferred to Japan.

From the current Chinese perspective, there are very few arguments to support the Japanese request that these islands are not occupied. According to Chinese legal opinion, there is a clear distinction between the view that the islands were «uninhabited» and the view that the islands «were not occupied». Historical sources prove the exact opposite, because before the Japanese discovery and occupation of Senkaku/Diaoyu, the islands were visited by Taiwanese fishermen whose graves have been preserved to this day. China's territorial claim is also justified by the fact that prior to the Japanese discovery of Senkaku/Diaoyu, it carried out some state acts such as providing navigation assistance to ships, collecting medicinal herbs and fishing. After the conclusion of the Peace Treaty of Shimonoseki in 1895, the Senkaku/ Diaoyu Islands came to Taiwan. By the end of the Second World War, the islands were returned to China. Notably, China persistently insists that, according to the Cairo Declaration and the Potsdam Proclamation rendered during the Second World War by Allied Powers (which Japan accepted as part of a peace treaty concluded in San Francisco in 1951), it was clearly stipulated that Japan was obliged to return China to the administration of these Islands, as well as to all other territories that Japan took over by force. In the Cairo Declaration of December 1943, Allied Powers obliged Japan to return all the territories that were seized by China forcefully. In the Potsdam Proclamation of 1945, Article 8 states that, «the provisions of the Cairo Declaration must be implemented and the sovereignty of Japan is limited to the islands of Honshu, Hokkaido, Kyushu, Shikoku, and other smaller islands». The Supreme Commander of the Allied Powers (SCAPIN) issued an instruction no. 677, which defines the administrative powers of Japan over these islands and about a thousand smaller islands, including Tsushima and Ryukyu islands north of the 30th parallel of the northern latitude. During the ceremony held on October 25,1945 , Taipei was officially returned to the Chinese Government. In a joint statement of 29 September 1972, the Government of Japan stated that, «it understands and respects the position of the Government of the People's Republic of China that Taiwan is an inalienable part of the territory of China and firmly supports its position under Article 8. The Potsdam Proclamation». In October 1945, Japan renounced the rights over Taiwan. However, the issue of territorial sovereignty over the Senkaku/ Diaoyu Islands was not explicitly solved. According to the Chinese standpoint, after the Japanese surrender at the end of the Second World War, Taiwan was returned to China along with the Senkaku/Diaoyu Islands [2].

Japan contests China's alleged argument by stating that its sovereignty on the Senkaku/Diaoyu Islands stems from Japanese continuing administration that began with the incorporation of Islands which dates back to the Sino-Japanese War and the conclusion of the Peace Treaty from Shimonoseki, and then on the basis of the absence of Chinese territorial claims in 1895-1970. Finally, Japan believes that it has sovereign rights on the Senkaku/Diaoyu Islands on the ground that they were affiliated to the group of Nansei Shoto islands which have no relation to Taiwan (whose government over Kuomintang was recognized for opportunistic reasons as a legitimate Chinese government until 1972), even with the San Francisco Peace Treaty concluded after the end of the Second World War in which China and Taiwan did not take part. The draft text of the Peace Treaty from San Francisco did not include the Senkaku/Diaoyu Islands, which shows that the creators of the Treaty did not consider that the said islands are part of the Taiwanese or Chinese territory [3, pp. 124-126]. In response to the 
possible omission of Senkaku/Diaoyu Islands from the final text of the Peace Treaty, on August 15, 1951, prior to the San Francisco Conference, the Chinese government publicly announced that: "If the People's Republic of China is excluded from the preparation, formulation and signing peace treaty with Japan, regardless of its content and outcome, it would be considered unlawful and invalid by the central national authority». In September 1951, the Chinese government sent another note stating that the San Francisco Peace Treaty was illegal and invalid and that the Government of Diaoyu Islands, China's Inherent Territory [4]. For thorough understanding of this problem, it is important to note that, on the basis of the San Francisco Peace Treaty, the Nansei Islands south of the 29th parallel of the northern latitude, were placed under the care of the United Nations and the civil administration of the United States of America. The US Administration of the Ryukyu Islands (USCAR), adopted on February 29, 1952, Regulation no. 68, and then on December 25, 1953 and Proclamation no. 27, which unilaterally extend the boundaries of this area on Senkaku/Diaoyu Islands [5].

Based on the Japan-US Treaty of Establishment of the Security Area of 1960, the United States was the administrator of Okinawa, including the Senkaku/Diaoyu Islands from 1945 to 1972 . Considering that there is a possibility of a different interpretation that could lead to an open territorial dispute, in August 1970, the Okinawa Assembly adopted a decision on the basis of which the Senkaku/Diaoyu Islands were declared as an integral part of the territory of Japan. This decision was supported by the National Parliament of Japan. That same year, Taiwan made an official protest, and China made similar complaints through public media demanding the return of the Senkaku/ Diaoyu Islands. On 17 June 1971, Japan and the United States signed the Agreement, which envisioned the return of Okinawa. The Okinawa Reversion Agreement also included the restoration of administrative authority over the Senkaku/ Diaoyu Islands from May 15, 1972. On the same day that the said Agreement was signed, the US Government issued a statement that the return of Okinawa would have no effect on the sovereignty over the Senkaku/Diaoyu Islands. On this occasion, the Ministry of Foreign Affairs of China made a protest on December 30, 1971, stating that the alleged conduct of the United States leading to an open violation of the territorial sovereignty of China is not acceptable to China and that it would therefore be necessary that United States return China its sovereign rights over the islands. The request came after the Council for the Coordination of the Joint Research on Mineral Resources in the Asian Overseas Area, under the auspices of the UN Economic Commission for Asia and the Far East (ECAFE), geophysical measurements began in 1968 since the report in 1969 stated that the area of the epicontinental plateau between Taiwan and Japan is rich in oil. However, the transfer of administration over the Senkaku/Diaoyu Islands to Japan did not provide the United States with an argument that would confirm the transfer of sovereignty. In truth, during the administration of the Senkaku/Diaoyu Islands, the United States did not contest the Chinese sovereignty or emphasized that Japan possessed this sovereignty. Officially, the United States insisted that the issues of sovereignty over the Senkaku/ Diaoyu Islands should be resolved between the interested parties. In October 1971, the United States declared that, «they believe that the return of the administration over the islands to Japan, from which the administration has previously been assigned, does not prejudice the enjoyment of these rights. The United States cannot extend the legal rights that Japan enjoyed prior to the transfer of island administrations, nor can they, after returning, be deprived of the rights of others who claim those rights. The United States does not belong to the islands and considers that the conflict over these islands should be resolved by the parties concerned». During the ratification of the Okinawa Reversion Agreement in 1971, the US State Department noted that the United States had a neutral position on the territorial demands of Japan and China for sovereignty over Senkaku/Diaoyu Islands. However, when the United States returned Okinawa under the sovereignty of Japan in 1972, Japan announced that they were involved in a dispute over Senkaku/Diaoyu Islands. In November 1996, Acting Deputy Assistant Secretary of Defense of the United States of America, Kurt Campbell, said that the provisions of the Treaty Establishing the Security Area between the United States and Japan of 1960 apply to the islands in question. Campbell also stated that the contractual obligation with regard to the contested islands does not mean that the United States recognizes Japanese territorial aspirations. He said: «The Agreement between the United States and Japan on the return of Okinawa to Japan explains that the Senkaku islands are under the control of Japan. This has been clearly specified by the United States for security reasons». Campbell also pointed out that the United States is not on either side in terms of the island dispute, and that the Agreement between the United States and Japan clearly lifted the border between the territory that Japan effectively operates and the territories legally belonging to Japan. The statement was interpreted as a balancing of the United States in relations between China and Japan [6, p. 155].

In connection with the above-mentioned actions of the United States and China, the Ministry of Foreign Affairs of Japan on March 8, 1972, issued a statement entitled: «The Basic View of Sovereignty over the Islands of Senkaku» [7]. That document repeated the claims of Japanese original sovereignty over the Senkaku/ Diaoyu Islands. Notably, Japan claimed that the islands were terra nulius, and that they had not belonged to Taiwan or the islands of the Pescadores before they were assigned to it by the Qing Dynasty on the basis of the Peace Treaty of Shimonoseki. China, according to the Japanese viewpoint, did not consider these islands as an integral part of Taiwan, and the islands could not have been included in the territories that Japan had renounced under the provision of article 2 of the San Francisco Peace Treaty. The Senkaku/Diaoyu Islands were placed under the administration of the United States of America as part of the Nansei Island in accordance with the provision of Article 3 of the said Peace Treaty. According 
to the Japanese view, the Senkaku/Diaoyu Islands were definitely returned to Japan in accordance with the Okinawa Reversion Agreement.

This view was completely unacceptable to China, so China expressed its view that the Japanese incorporation of Senkaku/Diaoyu Islands as terra nulius constitutes an unlawful act of occupying a Chinese territory that had no effect in international law. The Treaty of Shimonoseki, by which Japan forced the Chinese dynasty Qing to give him Taiwan, along with all of the associated islands, including the Senkaku/Diaoyu Islands, is of no legal significance, as confirmed by the acts of the Allied Forces of the Second World War - the Cairo Declaration and the Potsdam Proclamation by which the Allied Powers obliged Japan to unconditionally return all the territories it had seized from China. The said acts clearly define the Japanese territory which does not include the Senkaku/Diaoyu Islands. These islands were not placed under the custody of the United Nations and the administration of the United States of America on the basis of the Peace Treaty from San Francisco. The United States arbitrarily extended custody to the Senkaku/Diaoyu Islands, which per se, represented the Chinese territory. The subsequent «return of administrative powers» over the Senkaku/Diaoyu Islands to Japan, represents for China an unlawful attempt by Japan to occupy the Chinese territory, which actually represents a sort of challenge to the post-war international order. However, despite open opposition, China was keen to freeze the existing conflict with Japan for some time, so in that sense, Chinese President Deng Xiaoping proclaimed a new foreign policy, «leaving aside territorial disputes» with Japan, «for the purpose of joint development» [8]. This approach led to the normalization of diplomatic relations in 1972 and signing the Treaty of Peace and Friendship in 1978. On the basis of the Treaty, the two sides agreed not to raise any further questions regarding the sovereignty over the Senkaku/Diaoyu Islands, but to leave the issue «for resolution to future generations». However, although the resolution of the problem was left behind, the territorial dispute between China and Japan has not been unfortunately resolved to this day. The dispute came to the surface again, as rich oilfields were discovered in the areas of their unilaterally declared exclusive economic zones. From that moment on, two sides have been askin each other for the delimitation of exclusive economic zones, and then the continental shelves. Chinese estimates of potential gas reserves on the entire shelf range from 175-210 trillion cubic feet. Foreign estimates of potential oil reserves on the shelf are as high as 100 billion barrels. Chinese estimates of 'proven and probable gas reserves of some 17.5 trillion cubic feet on the Chinese side, much of it in the Xihu Trough. Japan and China assume rich petroleum deposits in the seabed around the disputed Islands, where the Japanese government speaks of over 94.5 billion barrels of quality oil [9].

China stands for the view that the line of demarcation must go along the edge of the epicontinental plateau that is approaching the Okinawa archipelago. On the other hand, Japan believes that the line of delimitation should go along the central line that separates a part of the coastal area of the two countries. Japan has repeatedly accused China of exploitation near the area belonging to the Japanese exclusive economic zone. China made a proposal for joint investment in the disputed area due to these allegations. Following several unsuccessful bargaining attempts and sending military troops to the disputed areas, the Chinese state overseas oil company China National Offshore Oil Corporation, began the exploitation of gas in the Shirakaba/Chunxiao which China considers to be 4 nautical miles inside the Chinese exclusive economic zone. Since Japan did not agree with China's stated approach, and believes the site was located on the other side of the border line, Japan tried to respond to the Chinese unilateral action by guaranteeing the right to exploit its Empire Oil Company in the Teikoku Sekiyu area. However, for security reasons, this company has never started business. The Ministry of Foreign Affairs of China has filed a protest note to Japan stating that this Japanese act was qualified for an open provocation and violation of Chinese sovereign rights. In the further course of events, the above outburst between Japan led to worsening of relations between the two countries.

The dispute gradually worsened and culminated in 1992, after the promulgation of the Chinese Law on the Territorial Sea and the Outer Seas. The Japanese Ministry of Foreign Affairs strongly protested against the new Chinese Law. Considering that in this case there can be no question of a territorial dispute, Japan strengthened the request for the Senkaku/Diaoyu Islands by giving some of them to private persons. In January 2003, the Japanese government announced that it rented the island of Kuba-shima/ Huangwei Yu, back to 1972, for 20 years. Kuba-shima/ Huangwei Yu, along with Okinawa, were hired by the United States for military purposes. For allegedly preventive reasons, the remaining three islands - Uotsuri-shima/Diaoyu Dao, Minamikojima/Nan Xiaodao and Kita-kojima/Bei Xiaodao were rented by the government of Japan in 2002. China reacted harshly to these unilateral acts issuing a protest note. The meeting of the President of China, Hu Jintao and the Japanese Prime Minister Yasuo Fukuda in 2008 caused some melting of mutual relations.

By the Agreement on joint exploitation of gas in Shirakaba/Chunxiao and Asunaro/Longjin areas concluded on June 18, 2008, the two sides principally declared that the East China Sea should not anymore be a crack of the conflict but rather the «Sea of peace, cooperation and friendship». The Agreement literally confirmed that it did not prejudice the merits of the set territorial claims, but was an agreement on mutual «understanding» for cooperation. In this regard, China and Japan decided to no longer undertake unilateral acts related to the exploitation of oil and gas in disputed areas until a final solution is reached. Given that China had already begun to exploit gas in the Shirakaba/Chunxiao area, it sent a call to Japan to provide technological support and invest in exploitation for the purpose of jointly generated profits. In relation to the gas sites of Asunaro- 
Longjin, the two countries concluded an Agreement on a common development zone of 2,700 square kilometers. The Agreement represented a milestone in improving bilateral relations between China and Japan [10]. However, due to the fact that China continued to use independently two controversial gas sources: Tianwaitian and Sankei, Japan protested that China was violating the provisions of the Agreement. For Japan, it was not acceptable that China had sovereign rights even to the area of the continental plateau almost to the Japanese island connected to the south by Okinawa, which overlaps with its exclusive economic zone of 200 nautical miles. Following the conclusion of the Agreement of 18 June 2008, along with the above-mentioned disagreement between China and Japan, the problem of South Korea's economic rights in relation to gas sources in the northern region of Asunar was also at the forefront. In addition to the above, South Korea is fighting China along the Socotra Rock offshore on which a Korean science base was built. China believes that building the base violated sovereign rights in its exclusive economic zone [11, pp. 9-12]. In 2009, China submitted to the SecretaryGeneral of the United Nations a preliminary notice on the establishment of the external border of its continental shelf beyond the 200 nautical miles. This notification was also realized through an official request of December 14, 2012, which, on a unilateral basis, formally extended its sovereign rights to the Okinawa Basin [12].

\section{UNILATERAL ATTEMPTS TO RESOLVE TERRITORIAL DISPUTES IN THE EAST CHINA SEA}

Japan ratified the 1982 United Nation Convention of the Law of the Sea in June 1996. After that, Japan adopted the Law on the Territorial Sea and the Contiguous Zone, as well as the Law on the Exclusive Economic Zone and continental shelf, which were supplemented by procedure for implementation. It also established an exclusive economic zone around the disputed Senkaku Islands. China ratified the 1982 United Nation Convention of the Law of the Sea 1996. In the ratification declaration, China confirmed its sovereignty over the territories which were mentioned in the 1992 Law on its Territorial Waters and their Contiguous Areas that included the disputed Senkaku/Diaoyu Islands. At the same time, China declared the precise location of straight baselines, which is important to delineate the Territorial Sea and the Contiguous Zone. According to the Chinese view, the straight baselines connected the base-points on the mainland coast and the outermost coastal islands [13; 14, p. 442]. In the Law it is set forth that the territorial sea extending 12 nautical miles from these baselines and from offshore islands. China's declaration of sovereignty over the Senkaku/Diaoyu Islands does not mean evidence of sovereignty over a continental shelf or exclusive economic zone extending from the features. Given to this, the baselines for the Territorial Sea including the baseline for the disputed Islands will be announced at a future date. Japan does not agree with China's base lines. In principle, straight baselines must be drawn to satisfy several requirements: they must not depart from the general direction of the coast, the sea areas lying within the lines must be sufficiently closely linked to the land domain to be subject to the regime of internal waters, they not be drawn to and from low-tide elevation, and shall not cut off the territorial sea of another State from the high seas of an exclusive economic zone [15, p. 6]. Both States claim their exclusive economic zones extending for 200 nautical miles (nm) from its coasts. China claims its exclusive economic zone on the basis of its continental shelf, which extends beyond Japan's declared area. From a topographical, a geomorphologic and a geological points of view, the continental shelf of the East China Sea is the continuity and underwater natural prolongation of the Chinese continent. The continental shelf of the Chinese continent ends at the Okinawa Trough. China holds that the Okinawa Trough, which does not follow the Japanese coast closely, proves that the continental shelves of China and Japan are not connected, and that the Okinawa Trough serves as a natural boundary between them. On the ground of that approach, which allows for claims up to $350 \mathrm{~nm}$ from the coast, China claims the area stretching extends from its coast up to the Okinawa Trough, which is within the $350 \mathrm{~nm}$ limit. China's continental shelf on this way represent an area which is extending throughout the natural prolongation of its land territory to the outer edge of the continental margin, i.e., presumably to the Okinawa Trough [16, p. 199]. China argues that the Okinawa Trough delineates the edge of the continental margin and that the axis of the Okinawa Trough thus serves as the boundary between the continental shelves of the two States.

Japan contests the Chinese interpretation and asserts that the Okinawa Trough basically cannot be considered a natural border. It argues that the Okinawa Trough is just an incidental depression in a continuous continental margin between the two States. In essence, Okinawa is sitting on the continental shelf. For this connotation Japan cited the International Court of Justice's precedent in the Case Concerning the continental shelf (Libya vs. Malta) where the Court concluded that, if there were a fundamental discontinuity between the continental shelf areas between adjacent States, the boundary should lie along the general line of the fundamental discontinuity. Japan claims that the continental shelf boundary should be the line equidistant between the undisputed territories of the two countries. It argues that the continental shelf should extend only to $200 \mathrm{~nm}$. It estimated that the exclusive economic zone of both sides overlap because the width of the East China Sea is less than $400 \mathrm{~nm}$ and therefore the median line drawn through the overlapping area westward of the disputed Senkaku/Diaoyu Islands should be the maritime border. Japan promulgated $200 \mathrm{~nm}$ of the exclusive economic zone from the straight baselines. It applies the median line method of delimitation, i.e., the line every point of which is equidistant from the nearest point on the baseline of Japan and the nearest point on the baseline from the breadth of the territorial sea pertaining to the foreign coast which is opposite the 
coast of Japan. Japan's proclamation to the west and north of the Senkaku/Diaoyu Islands remained unclear. The extent of overlapping is unknown because neither China nor Japan published maps or specified exclusive economic zone with coordinates the limits of their claims in the East China Sea.

In 1998, China promulgated the Exclusive Economic Zone and Continental Shelf Act which did not mention any specific geographical areas. However, this Act opened the door for settlement with Japan on the basis of international law and in accordance with the principle of equity. On the other hand, the Japanese Law on the exclusive economic zone and continental shelf gives possibility for both sides to stipulate boundary which may be agreed as a substitute for the median line. However, as long as the border is not agreed upon by neither of the sides, for China the disputed area is therefore between the Japanese-proposed median line and the Okinawa Trough, and for Japan it is the overlapping area of the 200 nm exclusive economic zone.

\section{APPLICABLE RULES TO BOUNDARY DELIMITATION IN EAST CHINA SEA}

The delimitation of sea areas has always had an international aspect [17, p. 132]. It cannot be dependent only upon the will of Japan or China as expressed in its municipal laws which established their exclusive economic zones and continental shelf. Territorial overlapping claims of China and Japan require maritime boundary delimitation. In principle, the validity of the delimitation with regard to other States depends upon international law. The determination of maritime boundaries is governed by international law that has evolved through and progressive development as reflected in the 1982 United Nation Convention of the Law of the Sea [18, p. 3].

According to the 1982 United Nations Convention on the Law of the Sea, one of the two applicable rules for delimiting maritime boundaries in the East China Sea is possible. The first begins with interpretation of article 76 which defines a coastal state's continental shelf as comprising the seabed and subsoil of the submarine areas that extend beyond its territorial sea throughout the natural prolongation of its land territory to the outer edge of the continental margin, or to a distance of 200 nautical miles from the baselines from which the breadth of the territorial sea is measured. Pragraph 6 of the same article 76 provides that, on submarine ridges, the outer limit of the continental shelf shall not exceed $350 \mathrm{~nm}$ from the baselines from which the breadth of the territorial sea is measured. China adheres to this rule of the natural prolongation of land territory, holding that East China Sea continental shelf is the natural extension of the Chinese continental territory. The Chinese continentalshelf claim extends all the way to the axis of the Okinawa Trough (about $350 \mathrm{~nm}$ from the China coast), enclosing in essence all of the oil potential resources in the East China Sea.

The second equally applicable rule safeguarded in the 1982 United Nations Convention on the Law of the
Sea for delimiting maritime boundaries, such as in the East China is by reference to the coastal States respective exclusive economic zones. Article 57 of the 1982 United Nations Convention defines a coastal State's exclusive economic zone as area which is not extending beyond $200 \mathrm{~nm}$ from the straight baselines from which the breadth of the territorial sea is measured. Japan and China are two States with opposite coasts, and the body of waters between them is less than $400 \mathrm{~nm}$ in total. The width varies from $180 \mathrm{~nm}$ at the narrowest points to 360 $\mathrm{nm}$ at the widest. It is $1,300 \mathrm{~km}$ (or $702 \mathrm{~nm}$ ) in length from north to south. The exclusive economic zones present a weighty overlap problem, because these areas, beyond and adjacent to their territorial sea, are subject to a specific legal regime established by the unilaterally promulgated act which is not entirely in conformity with the 1982 United Nation Convention.

The 1982 United Nations Convention contains identical provisions dealing with the delimitation of exclusive economic zone and delimitation of the continental shelf. Hypothetically, a solution is given in accordance with Article 74 and Article 83 of the 1982 United Nations Convention, which set the delimitation of the maritime zones (exclusive economic zone and continental shelf) between Japan and China as the States with opposite coast. In compliance to these rules, the delimitation should be effected by agreement on the basis of international law, as referred to in Article 38 of the Statute of the International Court of Justice [19, pp. 373-401].

First and foremost, the States are bound to apply equitable principles as part of international law to balance up the various considerations which it regards as relevant in order to produce an equitable solution. The goal of achieving an equitable solution when establishing the delimitation of both of continental shelf and of exclusive economic zones requires application of customary law [20, p. 59]. Essentially, customary international law and the 1982 United Nations Convention on the Law of the Sea require an equitable result. A logical question arises whether it will be equitable solution if the continental shelf and exclusive economic zone share a common maritime boundary. From the recent case law, there is a trend towards delimitation of single maritime boundary for all the overlapping zones between opposite and adjacent States. Most States would regard this as a pragmatic and workable solution. Whether the boundary of the continental shelf areas and the boundary of the exclusive economic zone have to be identical, depends on the result of delimitation. Few principles of delimitation may be applied under the condition of equitable principles. The first one is the proportionality that is based upon the relationship between the lengths of the relevant coasts of States whose maritime zones have to be delimited, on the one hand, and the area of maritime space to be allocated to each of the parties by the delimitation, on the other. The second one is principle of distance that is not opposed to the principle of proportionality, a contrario, both principle are complementary and both 
remain essential elements in the process of delimitation [21, p. 13]. Application of equitable principles, including abstention from refashioning nature, non-encroachment by one party on the areas appertaining to the other, respect due to all relevant circumstances and the notions that equity (ex aeqo et bono), which does not mean that equality has to be referred on occasion of the delimitation of maritime boundaries between Japan and China [22, pp. 18; 23, pp. 56-58].

In the absence of equitable solution, the Japanese unilaterally drew a median line, which is rejected by China on the ground that it is in favour of Japan. The median line does not only turn into the Chinese side, but also turns to the west to enclose the disputed Senkaku/Diaoyu Islands on the Japanese side of the line. Japan considers all waters east of this unilaterally drawn median line to be Japanese territory. China argues that the delimitation should be effected only by agreement, and that agreement through consultation takes precedence over the equidistant line principle. Its representatives pointed out, that median line or equidistance line is only a method in the delimitation of the sea, which should not be defined as the method that must be adopted, still less as the principle for the delimitation [24]. The delimitation of the sea should follow the fundamental principle, i.e. the equitable principle. In some cases, if equitable and reasonable results in the delimitation may be achieved by using the method of median line or equidistance line, the States concerned can apply it by agreement [25, p. 111-118].

The question of delimitation of maritime border between Japan and China in East China Sea is obliviously common with the dispute over the sovereign rights to the Senkaku/Diaoyu Islands. China and Japan argue that they have inviolable sovereignty over the Islands. The disagreement over the evidence of ownership can be summarized as follows. China argues that the Senkaku/ Diaoyu Islands had been part of its territory until April 17, 1895, when they were ceded to Japan after losing a war. The Chinese contend that the islands should have been returned under the terms of Article 2 of the San Francisco Treaty of 1951. Therefore, according to China, whatever happened after April 1895 cannot detract from China's longstanding claim. Japan bases its case on the contention that the islands had belonged to no country until January 1895 , when they were incorporated into Japanese territory by a cabinet decision. It argues further that since that time, Japan has maintained continuous and effective control of the islands, and therefore what happened before January 1895 cannot diminish Japan's sovereignty. For the purpose of this analysis, it will be important to clarify whether these islands allow the holder State to claim an exclusive economic zone and a continental shelf. Actually, the Senkaku/Diaoyu Islands territories administered by Japan are also claimed by China. The Senkaku/Diaoyu Islands Islands consist of five uninhabited islets and three inhospitable rocks, located just about $120 \mathrm{~nm}$ southwest of Okinawa. They are situated at the edge of the East Chine Sea's continental shelf fronting the Okinawa Trough to the south. The depth of the surrounding waters is about
100-150 meters, with the exception of a deep trough in the continental shelf just south and east of the islands, that separates them from the Ryukyu Islands. According to article 121(3) of the 1982 United Nations Convention of the Law of Sea, rocks which cannot sustain human habitation or economic life of their own shall have no exclusive economic zone or continental shelf. Japan and China agree that the islands generate the right to a $12 \mathrm{~nm}$ territorial sea and to a $12 \mathrm{~nm}$ contiguous zone, but whereas China applies article 121(3) and thus denies the islands the right to an exclusive economic zone and continental shelf, Japan upholds such argues. It means that Japan holds that the features are islands and are therefore entitled to have continental shelves and exclusive economic zones. It thus uses them as base points for its continental shelf and exclusive economic zone claims in the East China Sea.

If Japan's interpretation of the 1982 United Nations Convention of the Law of the Sea is accepted, then it can claim up to an equidistant line with China. If China is given the title to the islands under such conditions, it could claim a continental shelf up to the Okinawa Trough, and an exclusive economic zone to an equidistant line with the nearest undisputed Japanese island. Otherwise both countries would have an overlapping continental shelf and exclusive economic zone claims extending from their nearest undisputed territory. China has not taken yet an official position on whether the Senkaku/Diaoyu Islands are a rock or an island, which means that only in the latter case the islands could be entitled to an exclusive economic zone. The answer to the question of ownership of the Senkaku/Diaoyu Islands is a prerequisite for pending to an agreement over the delimitation of the maritime border between Japan and China.

\section{POTENTIAL SOLUTIONS FOR REGULATION OF TERRITORIAL DISPUTES IN THE EAST CHINA SEA}

In accordance with the United Nations 1982 Convention on the Law of the Sea, the delimitation of the sea should be conducted first through consultation and by agreement between parties concerned. It means that in the delimitation of the East China Sea the choices of the parties concerned should be respected to the greatest extent. As long as Japan and China can reach an agreement, any method of the delimitation, provided it can be accepted by the parties concerned, is reasonable. After years of dispute over gas fields in the East China Sea, Japan and China have reached a mutual agreement announced on 18 June 2008. The agreement was made in a spirit of understanding and cooperation. In the current agreement, the two countries agreed to stand the border issue for the time being and promised to refrain from unilaterally exploiting the disputed areas until a resolution was found. The new agreement affects two of the disputed gas fields: Shirakaba/Chunxiao and Asunaro/Longin. In the case of the Shirakaba/Chunxiao field, which China has already started to develop, Japan has been invited to invest in its development. As for the Asunaro/Longjin gas field, China and Japan have agreed on establishing a joint development zone. The agreement represents a milestone 
in the improvement of bilateral relations between China and Japan [26]. Regarding delimitation of their maritime border, Japan and China are free to adopt whatever delimitation line they wish, whether that line is based on political, economic, geographic or any other kind of consideration. On the basis of the rule, the land dominates the sea; Japan and China have liberty to point out particular potential solutions for delimitation of the «inherited» maritime zones (continental shelves and exclusive economic zones). In fact, it means that Japan and China should be obliged to determine the existing facts on basis of the rules of international law which are fundamental for delimitation of maritime border of States with opposite coasts. In order to achieve an equitable solution, Japan and China should take a wider consideration of all facts, principles and rules within the context of general international law. It anticipates the principle of equidistance or different equitable principles of delimitation (historic titles or other special circumstances such is the geographic configuration, geomorphological and geological factors of the seabed and subsoil, economic factors, political and security factors, enviroment, present of third States, etc.). In the near future, Japan and China should make every effort to negotiate a solution on a common boundary line for both the exclusive economic zones and continental shelves. Such boundary lines between Japan and China are crucial for East Asian security and joint development of fish, minerals, and hydrocarbon resources, which greatly depends on the two regional powers. If no agreement is reached within a reasonable period of time, Japan and China should resort to the conciliation procedures provided for in Part XV of the 1982 United Nation Convention. Either State then may resort to compulsory procedures provided for in the Convention by submitting the dispute to the International Court of Justice, the International Tribunal for the Law of the Sea or to the Arbitration [27, pp. 68-77].

\section{SUMMARY}

The previous analysis has made it clear that there are serious differences between Japan and China regarding the determination of sovereignty over the Senkaku/ Diaoyu Islands, which is a preliminary issue for the delimitation of the sovereign rights of the two States in the East China Sea. In this respect, the following differences are crucial.

Although China and Japan agree that the possession of sovereignty over islands entails the right to a territorial sea of up to 12 nautical miles and up to 12 nautical miles on the contiguous zone, they disagree about the possibility of declaring exclusive economic zones and the continental shelves. On the one hand, Japan supports China's position towards a consistent application of Article 121 (3) of the 1982 United Nations Convention on the Law of the Sea, which stipulates that the possession of cliffs and rocks in which people can not live and where it is not possible to develop independent economic life does not entail the right to declare exclusive economic zones and continental shelves. On the other hand, Japan does not consider that the Senkaku/Diaoyu Islands can not have their exclusive economic zones and the continental shelves. By this approach, Japan basically confirms that Senkaku/Diaoyu Islands is viewed as islands, and not as cliffs or rocks whose status by law must not entail the right to proclaim those seas. If the Japanese interpretation of the 1982 United Nations Convention on the Law of the Sea is accepted, then Japan could claim that the delineation with China in the East China Sea goes by a central line or a line of equal distance. However, in the event that it is established that China has sovereign rights over the Senkaku/Diaoyu Islands, it could require the establishment of its continental shelves all the way to the Okinawa Basin and the proclamation of its exclusive economic zone on a line of equal distance with the closest Japanese island in respect of which there is no dispute. In the case of a contrario, both States would retain territorial aspirations on the continental shelves and the exclusive economic zones of the other that overlap and stretch from their nearest territories that are not disputed. Since China has not yet taken an official stand on whether Senkaku/Diaoyu represents rocks or islands, the issue of sovereignty over the disputed sea area will be a preliminary legal issue that needs to be answered before any agreement on territorial delineation in the East China Sea is made.

Therefore, it seems clear, that China and Japan must resolve their territorial dispute by mutual consent and in accordance with the rules and principles of international law codified in the 1982 United Nations Convention on the Law of the Sea, but also contained in the customary international law. Moreover, achieving a legally sustainable solution to sovereignty over the Senkaku/Diaoyu Islands through peaceful settlement of the dispute foreseen in Chapter XV of the 1982 UN Convention, includes improving the Sino-Japanese relations that are burdened by mutual misunderstanding, nationalist animosities, geopolitical and historical rivalries [28].

\section{References}

1. Joyman Lee. Senkaku/Diaoyu: Islands of Conflict. History Today, 2011, Vol. 61, no. 5. Availiable at: http:// www. historytoday.com / joyman-lee / senkakudiaoyuislands-conflict (accessed 30.09.2017) [in English].

2. Diaoyu Dao, an Inherent Territory of China. Availiable at:http://english.people.com.cn/90785/7960320. html (accessed 30.09.2017) [in English].

3. Seokwoo Lee. The 1951 San Francisco Peace Treaty with Japan and Territorial Disputes in East Asia. Pacific Rim Law \& Policy Journal, 2002, Vol. 11, no. 1 [in English].

4. Information Office of the State Council of the People's Republic of China. Availiable at: http:// ba.chineseembassy.org / eng / zt / dydwteng / t986956. htm (accessed 30.09.2017) [in English].

5. Treaty of Peace with Japan. 8 September 1951. 3 U.S.T. 3169 [in English].

6. Mark J. Valencia. The East China Sea Dispute: Context, Claims, Issues and Possible Solutions. Asian perspective, 2007, Vol. 31, no. 1 [in English].

7. The Basic View of Sovereignty over the Islands of Senkaku. Availiable at: http://www.mofa.go.jp/region/ asia-paci/senkaku/basic_view.html (accessed 17.08.2017) [in English].

8. PRC Foreign Ministry. Set Aside Dispute and Pursue Joint Development. November 17, 2000 [in English].

9. Selig Harrison Selig, ed. Seabed petroleum in Northeast Asia: Conflict or cooperation? Woodrow Wilson International Center for Scholars. Washington D.C., 
2005. Availiable at: http://www.wilsoncenter.org/index. cfm?topic_id $=1462 \&$ fuseaction=topics.documents\&group id=132299 (accessed 25.08.2017) [in English].

10. Ralph A. Stamm. China, Japan: Getting sensible, finally. ISN Security Watch, 30 June, 2008 [in English].

11. Ji Guoxing. Maritime Jurisdiction in the Three China Seas: Options for Equitable Settlement. In: Policy Papers. Institute on Global Conflict and Cooperation. UC Berkeley, 1995 [in English].

12. Submissions to the Commission: Submission by the People's Republic of China. Availiable at: http://www. un.org/Depts/los/clcs_new/submissions_files/submission_ chn_63_2012.htm (accessed 30.09.2017) [in English].

13. Reisman W. M., Westerman G. S. Straight Baselines in International Maritime Boundary Delimitation. New York, 1992 [in English].

14. Liyu Wang and Peter H. Pearse. The New Legal Regime for China's Territorial Sea. Ocean Development and International Law, 1994, Vol. 25, no. 4 [in English].

15. Handbook on the Delimitation of Maritime Boundaries. Division for Ocean Affairs and the Law of the Sea Office of Legal Affairs. United Nations. New York, 2000 [in English].

16. Zhiguo Gao. China and the LOS Convention. Marine Policy, 1991 [in English].

17. Fisheries Case. Judgment of December 18th, 1951. International Court of Justice Reports, 1951 [in Russian].

18. Convention on the Law of the Sea with Annexes and Index. Final act of the Third UN Conference on the Law of the Sea. UN Treaty Series, Vol. 1833 [in English].

19. Shigeru Oda. International Law of the Resources of the Sea. Recueil des Cours Académie de Droit International, 1969, Vol. 127, Vol. I [in English].
20. Delimitation in the Maritime Area between Greenland and Jan Mayen (Denmark v. Norway). International Court of Justice Reports, 1993 [in English].

21. Continental Shelf Case (Libya v. Malta). International Court of Justice Reports, 1985 [in English].

22. Continental Shelf Case (Tunisia v. Libya). International Court of Justice Reports, 1982 [in English].

23. Case Concerning the Continental Shelf (Libyan Arab Jamahiriya v. Malta). International Court of Justice Reports, 1985 [in English].

24. Zhu Fenglan. The Delimitation of East China Sea Continental Shelf: Sino-Japanese Disputes from the Perspective of International Law. China International Studies, 2006 [in English].

25. Gerald H. Blake. Mediterranean Micro-Territorial Disputes and Maritime Boundary Delimitation. Il regime giuridico internazionale del Mare Mediterraneo. U. Leanza, Milano, 1987 [in English].

26. Ralph A. Stamm. China, Japan: Getting sensible, finally. ISN Security Watch, 30 June, 2008 [in Russian].

27. Duško Dimitrijević. International Law Regulation of Territorial Dispute in the East China Sea between Japan and China. Review of International Affairs, 2011, Vol. LXII, No. 1133 [in English].

28. Reinhard Drifte. Japanese-Chinese territorial disputes in the East China Sea - between military confrontation and economic cooperation. In: Working paper, Asia Research Centre, London School of Economics and Political Science. London, 2008. Availiable at: http:// eprints.lse.ac.uk / 20881 / http: // www.un.org / Depts/ los/clcs_new/submissions_files/submission_chn_63_2012. htm (accessed 30.09.2017) [in English].

Дуико Димитриевич*

\title{
ТЕРРИТОРИАЛЬНЫЕ СПОРЫ В ВОСТОЧНО-КИТАЙСКОМ МОРЕ
}

\begin{abstract}
Вопрос территориального разграничения в Восточно-Китайском море имеет геоэкономическое значение из-за наличия богатых источников энергии, а также переплетенных интересов прибрежных государств и Соединенных Штатов, которые по стратегическим причинам имеют тенденцию поддерживать политическое и военное присутствие и контроль. В последнее десятилетие Китай, Тайвань и Япония усилили свои территориальные требования в Восточно-Китайском море над островами, которые китайцы называют Дяоюй, тайваньским Дяоютай и японским Сенкаку (в дальнейшем - острова Сенкаку/Дяоюй). Из-за все более заметной эскалации взаимоотношений, возникающих из-за разных точек зрения относительно суверенитета этих островов и различных подходов к определению границ исключительных экономических зон и континентальных шельфов, где ни одна из сторон не хочет идти на уступки другой стороне, применение международного права представляется неизбежным механизмом преодоления территориальных споров. В этой связи в исследовании рассматриваются возможности разрешения территориальных споров в Восточно-Китайском море в целях обеспечения устойчивых правовых решений, которые будут соответствовать международному морскому праву и применение которых обеспечило бы мир и стабильность в этой части Земного шара.
\end{abstract}

Ключевые слова: территориальные споры, морская делимитация, ВосточноКитайское море, острова Сенкаку / Дяоюй, Китай, Тайвань, Япония.

\footnotetext{
* Димитриевич Душко (dimitrijevicd@diplomacy.bg.ac.rs), Ph.D., профессор и экс-директор Института международной политики и экономики, 11103, Белград, ул. Македонска, 25, Сербия.
} 